\title{
症例報告
}

\section{チワワの眼瞼縁に限局した特発性非感染性肉芽腫症の 1 例 Idiopathic Sterile Granulomatosis at Only Edge of the Eyelids in a Chihuahua}

\author{
藤森基成 ${ }^{1)} *$ 泉 憲明 ${ }^{2)}$ 永田雅彦 ${ }^{3)}$ \\ 1)ふじもり動物病院, ${ }^{2)}$ いずみ動物病院, ${ }^{3)} \mathrm{ASC}$ どうぶつ皮膚病センター \\ Motonari Fujimori $^{11 *}$, Noriaki Izumi ${ }^{2)}$, Masahiko Nagata ${ }^{3)}$ \\ ${ }^{1)}$ Fujimori Animal Hospital, ${ }^{2}$ Izumi Animal Hospital, ${ }^{3)}$ Animal Dermatology Center, ASC
}

\begin{abstract}
要 約:2歳齢, 雄のロングコート・チワワの両眼瞼縁に限局し徐々に悪化する丘疹の集簇を認めた。 経口抗生剂にて改善なく皮膚病理組織検査を施行したところ, 真皮に多巣状の化膿性肉芽腫を認め た。PAS染色で菌要素を認めず特発性非感染性肉芽腫症と診断した。経ロプレドニゾロン $1.0 \mathrm{mg} / \mathrm{kg}$ SID にて 1 週間で劇的に改善した。

キーワード：眼瞼, チワワ, 肉芽腫
\end{abstract}

\begin{abstract}
A two-year-old, male long-coat Chihuahua presented with slowly progressive grouped papules at only edge of the eyelids. Antimicrobial was not effective, then skin biopsy was performed. Histopathologic examination of the lesion revealed multi-focal pyogranuloma in the dermis. This present dog was diagnosed as having idiopathic stelie granulomatosis, and the lesions were improved with one week course of oral prednisolone $1.0 \mathrm{mg} / \mathrm{kg}$ SID dramatically.
\end{abstract}

Key words: eyelids, Chihuahua, granulomatosis

(Jpn J Vet Dermatol 2006, 12 (4): 247-249)

\section{緒 言}

肉芽腫とは硬い持続性の結節状炎症性病変で，その 多発例を肉芽腫症としている。これはある種の微生 物・寄生虫・異物などの組織内への侵入に反応して形 成されるマクロファージの集簇巣であり, 周囲に線維 結合組織の増生，リンパ球等の浸潤を伴う2)。犬では 特発性非感染性肉芽腫および化膿性肉芽腫症候群と呼
称される疾患枠があり，本症は原因・発症メカニズム が明らかにされていない非感染性皮膚肉芽腫である1)。 明らかな性差や好発年齢はなく，様々な犬種に発生す るが，ダックスフンド，イングリッシュ・ブルドッグ, ゴールデン・レトリバーおよびグレート・デンに好発 するといわれている ${ }^{1)}$ 。今回，チワワにその一型と思 われる臨床像と皮膚病理組織像を呈した特発性非感染 性肉芽腫症を経験したので報告する。

\footnotetext{
*連絡先：藤森基成（ふじもり動物病院） † 486-0842 愛知県春日井市六軒屋町 2-3-2

TEL 0568-87-7017ＦAX 0568-87-7018Ｅ-mail: motovet@muf.biglobe.ne.jp

*Correspondence to: Motonari Fujimori (Fujimori Animal Hospital) 2-3-2 Rokkenyacho, Kasugai, Aichi 486-0842, Japan
} 

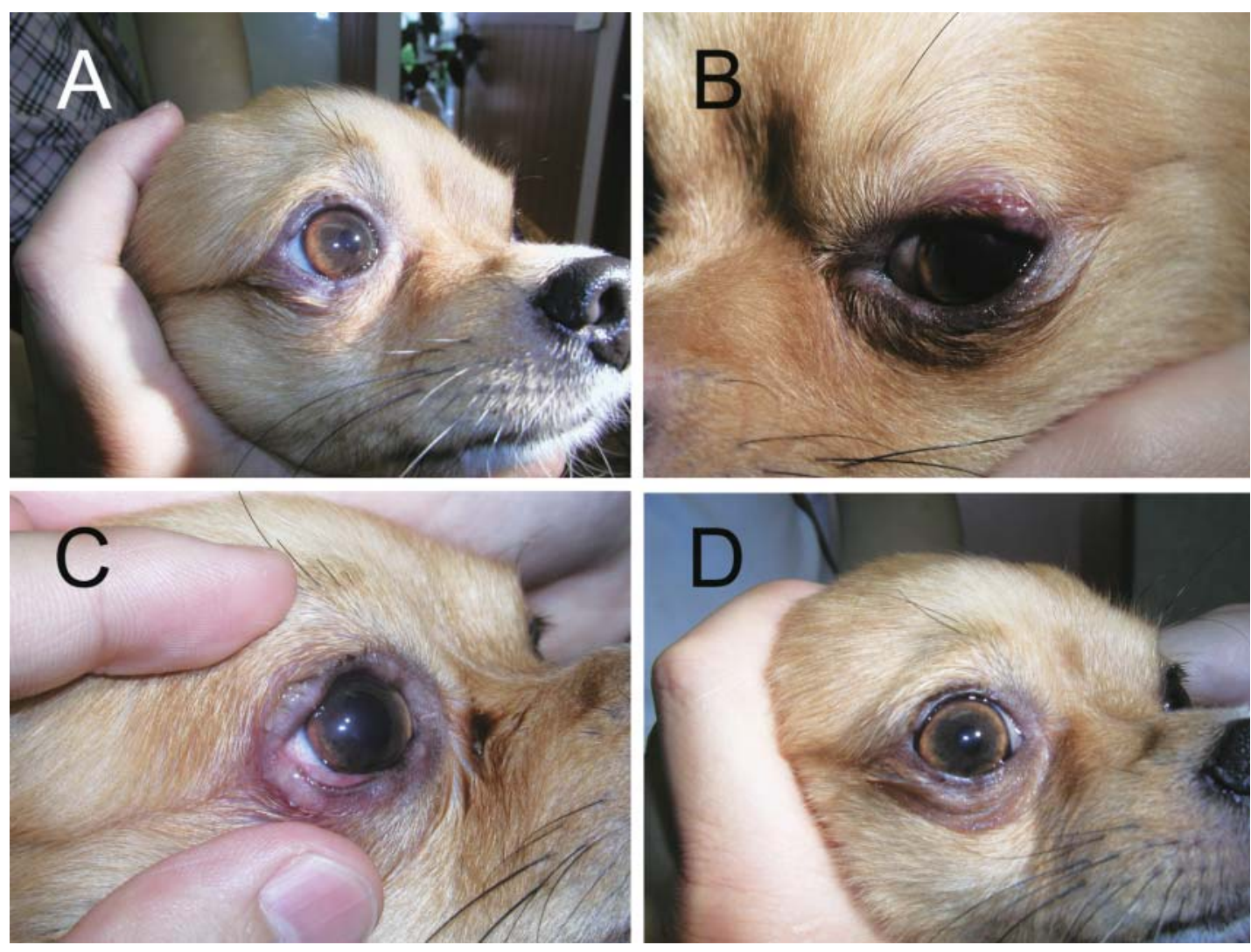

Fig. 1. Clinical features. (A) Note grouped papules at edge of the right eyelid at the initial examination. (B) Note grouped papules at edge of the left eyelid at the initial examination. (C) Note exacerbated lesions after oral antimicrobial administration. (D) Note improved lesions after oral prednisolone administration.

\section{症 例}

ロングコート・チワワ，未去勢雄，体重 $2.55 \mathrm{~kg}_{\circ} 2-$ 3 日前から右下眼瞼縁に $3 \mathrm{~mm}$ 程の表皮異常を伴わない 常色丘疹の散在を認めた(Fig. 1A)。細菌感染を考慮し, 抗生剂 (クレラムフェニコール) と非ステロイド系消炎 剤 (アズレン)の点眼薬を処方したが改善なく，左眼瞼 にも同様の皮疹が発生した (Fig. 1B)。身体検査で特記 すべき異常なく，体表リンパ節の腫大も認められな かった。セファレキシンの経口投与でさらに経過観察 を行ったが皮疹は拡大し，一部に糜爛を呈したことか ら皮膚生検を行った (Fig. 1C)。血液検査で異常值は認 められなかった。また細菌培養検査は行っていない。

皮膚病理組織学的検査では，真皮において毛細血管 の拡張とともに好中球やリンパ球を混じた組織球様細 胞主体の結節状浸潤が多巣性に認められた（Fig. 2A， B）。なお病巣はマイボーム腺の分布に一致せず，PAS 染色で寄生体もみられなかった。組織像は真皮におけ
る化膿性肉芽腫を呈しており，明らかな異物や感染要 素がみられなかったこと, また発熱やリンパ節の腫脹 なども認められなかったことから，特発性非感染性化 膿性肉芽腫および肉芽腫症候群の一型を予想した。

治療としてプレドニゾロン $1.0 \mathrm{mg} / \mathrm{kg}, 1$ 日 1 回経口 投与をおこなったところ，皮疹は約 1 週間で劇的に改 善し(Fig. 1D)，休薬6力月後の現在も皮疹の新生は認 められない。

\section{考 察}

自験例の肉芽腫症は眼瞼縁に集簇し, 細菌感染に合 致した全身の症状や治療経過を示さず，皮膚病理組織 学的検査は霰粒腫や麦粒腫を示唆するマイボーム腺に 限局した炎症と異なっていた。臨床像より若年性蜂窩 織炎が鑑別と考えたが，本症は皮膚病変とともに発熱 とリンパ節腫脹を特徴としており，自験例はこれら皮 膚科以外の症状を欠いていた。以上より, 特発性非化 

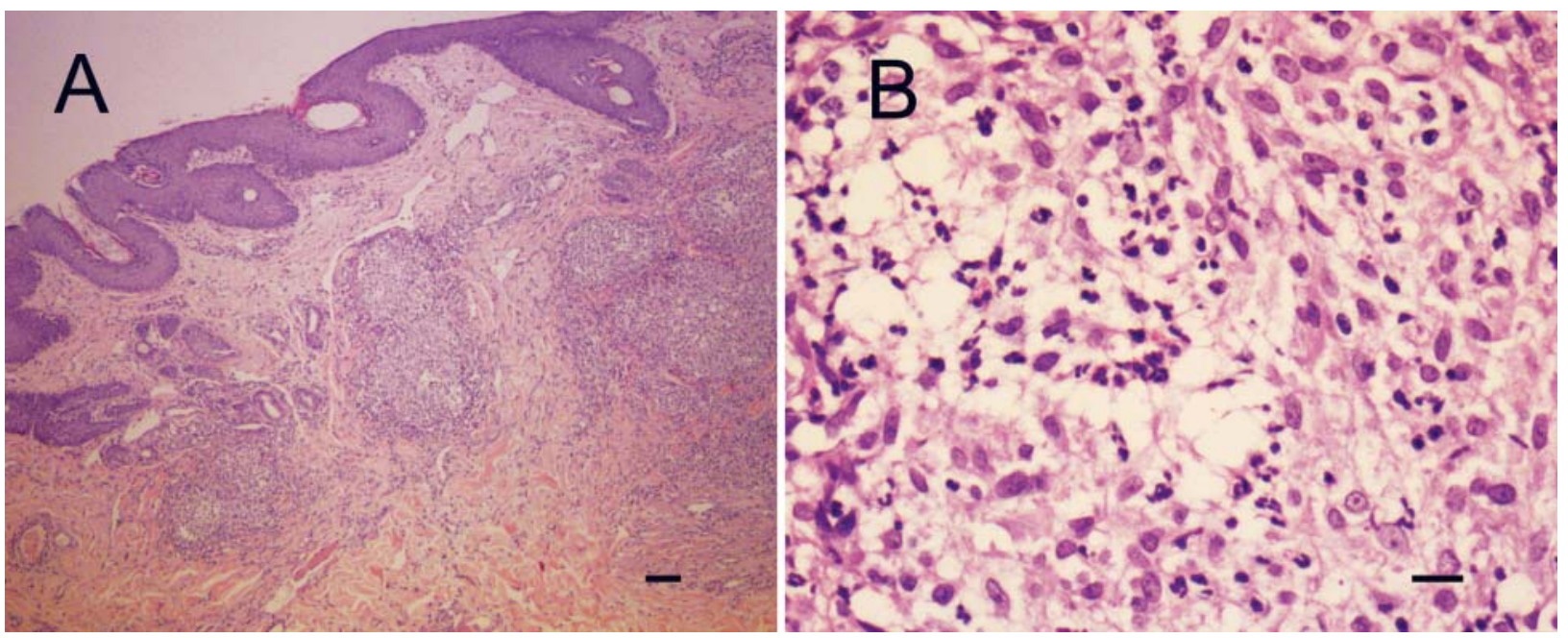

Fig. 2. Histopathologic findings. (A) Note multi-focal, nodular inflammation in the dermis (H\&E stain, Bar=500 $\mu \mathrm{m})$. (B) Note neutrophils, lymphocytes, and histiocytes infiltration at the lesions (H\&E stain, Bar=10 $\mu \mathrm{m})$.

膿性肉芽腫抢よび肉芽腫症候群に相当する疾患と思わ れたが，チワワの眼瞼縁に環状に集簇した臨床像から 特発性非感染性化膿性肉芽腫㧍よび肉芽腫症候群の典 型とは言えず，その一型と診断するのが妥当と判断し た。推測の域は出ないが, 自験例では眼瞼だけに丘疹 が集簇しステロイドが奏効したことから，眼瞼への何 らかの刺激による免疫応答，あるいは犬種固有の皮膚 機能が関与した肉芽腫症ではないかと考えた。今後さ らに症例を集積し，疾患の独立性や病因に関する解析 が必要と思われた。

\section{引用文献}

1) Scott, D.W., Miller, W.H. and Griffin, C.E. 2000. pp. 1136-1140. In: Small Animal Dermatology, 6th ed, W.B. Saunders, Philadelphia.

2）代田欣二. 2004. 獣医臨床皮膚科 10: 139-141.

3) Rothstein, E., Scott, D.W. and Riis, R.C. 1997. J. Am. Anim. Hosp. Assoc. 33: 540-543. 